\title{
Evaluation of Risk of Fluctuation Claim on Cost of Construction Projects in the South-South Zone of Nigeria
}

\author{
Anjiba D. Lamptey-Puddicombe ${ }^{1, *}$, Adu T. Emmanuel ${ }^{2}$ \\ ${ }^{1}$ Quantity Surveying Department, Rivers State University, Rivers State, Nigeria \\ ${ }^{2}$ Quantity Surveying Department, University of Uyo, Akwa Ibom State, Nigeria
}

Copyright $@ 2018$ by authors, all rights reserved. Authors agree that this article remains permanently open access under the terms of the Creative Commons Attribution License 4.0 International License

\begin{abstract}
Establishment and achievement of accurate project estimate is a major challenge facing the construction industry across the nations especially in the developing countries. Projects generally are one-off activities with very unique characteristics. Their acyclic nature further makes them practically difficult to repeat any section if that is completed, thereby subjecting their original schedule, budget and performance baselines to the prevailing project environment shaped by both known and unknown financial, technical and managerial risk factors. The study established the relationship between fluctuation cost and cost overrun of building construction projects in the South-South zone of Nigeria. The cost data on 20 completed public building construction projects in the study area were purposively sampled and adopted for the study. Data obtained were analysed using linear regression. The result revealed that fluctuation in the prices of construction materials and labour accounts for $97 \%$ on the cost overrun of building projects in the South-South zone of Nigeria. It is therefore recommended that practitioners in the construction sector should adequately provide for likely fluctuation of material and labour prices during project planning for successful implementation.
\end{abstract}

Keywords Building Project, Claims, Cost Variation, Fluctuation, Risk

\section{Background of the Study}

Construction industry is one of the major industries that contribute significantly to the growth of socio-economic development of a nation. Construction is an employment spinner. "Construction" covers a spectrum ranging from slow, certain, and simple (stodgy) projects on one end to quick, uncertain, and complex (dynamic) projects on the other

[4].The construction sector is responsible for construction of new houses, renovation of old structures, construction of roads, bridges, complex structures, among many other things. The construction industry is however associated with a high risk exposure which calls for risk management in order to ensure it success. A project is considered successful when it accomplishes its technical or performance requirements, maintains its schedule and remained within the budgetary baseline. For many successful project teams; their abandonment on project completion is regrettable, destabilizing,[12].This implies that, the degree to which a project meets its original planned cost, time and performance requirements determines its degree of success. Over the years, the difficulty in predicting future project events, with high level of precision has made the realization of successful project globally a nightmare.

Several parts of the world including Nigeria had witnessed many projects being cancelled before the completion date. Other projects being completed late and cost well over their original budgets. A comprehensive research made on cost overruns in global construction revealed that 9 out of 10 projects had overruns [10]. Survey conducted revealed that fifty-eight percent $(58 \%)$ of respondents experienced time overrun on their projects with the length of delay averaging forty-eight days from the point of anticipated completion to the actual finishing date[6]. On the budget front, clients were critical of the industry's inability to keep to the agreed contract budget; thirty-two percent (32\%) of projects exceeding the agreed sum. Fifty-seven percent (57\%) of clients experienced defects on their project sufficient to cause a delay to project handover [25].The trend of overrun is more severe in developing countries where these overruns exceed $100 \%$ of the anticipated cost of the project [3]. It is believed that the inability of project members and practitioners in the 
construction industry particularly in the building sub-sector to meet these key baselines is due largely to their inability to predict and provide for the known and unknown risk events that should they occur will have serious impact on the project triple-constraints of time, cost and performance. This has resulted to added costs, poor quality, increased cost of rework and ultimately project abandonment.

Price fluctuation has been identified as one of the major risks causing cost overrun and it is attributed to inflation of price of material and labour in developing countries or the speculation of suppliers [16].The aim of this study therefore is to determine statistically the degree to which change in material and labour prices of construction projects affect the cost of building projects. In line with the objective of this study, the hypothesis is stated that: There is no significant correlation between fluctuation and project cost variation.

\section{Statement of Hypothesis}

H0: There is no significant correlation of fluctuation claim and project cost variation

H1: There is significant correlation of fluctuation claim and project cost variation

\section{Literature Review and Conceptual Framework}

This section contains a review of literature on the concept of risk management in construction, the difference between risk and uncertainty and various risk factors affecting construction project performance.

\section{The Concept of Risk Management in Construction}

"Risk" and "uncertainty" are synonymous terms and are often used interchangeably in the construction industry. [9] Described risk as the threat of a loss (e.g., financial, timescale, or performance) depending on whether a given event may or may not happen. [20] defined risk in construction as "a variable in the construction process whose variation results in uncertainty as to the final cost, duration and quality of the project”. [17] viewed risk as the potential for complications and problems with respect to the completion of a project and the achievement of a project goal.Risk is a possible undesirable and unplanned event that could result in the project not meeting one or more of its objectives [28] [9] clearly described uncertainty as the difference between an anticipated or predicted outcome (e.g. a cost estimate) and the confirmed outcome (e.g. the actual cost). [11] Opined that, it is the lack of predictability about a problem structure, outcomes or consequences in a decision or planning situation that result to risk in projects. [22] Defined project risk as "an uncertain event or condition that, if occurs, has a positive or a negative effect on at least one project objectives, such as time, cost, scope, or quality". Researchers have established relationship between the two terms in the literature. According to [14] uncertainty creates risk and that the extent of the risk will depend on the level of uncertainty and its consequence for the project. One is measurable uncertainty; the other is immeasurable risk [21]. The two terms are however used interchangeably in the construction industry due to its peculiar characteristics compared to other industries.

Risk management is a management tool that aims at identifying sources of risk, determining their impact and developing appropriate responses [24] [26]defined risk management as an organisation process of identifying and measuring risk and then developing, selecting, implementing and managing options for addressing them. A manager of risk must therefore act explicitly in advance to prevent its occurrence or at worst minimize its impact on the baselines estimates of the project. The risk management process is concerned with identifying, analysing, and taking action against project risks, which also includes maximizing the results of positive events and minimizing the consequences of adverse or uncertain events[15]. [7] suggested that the processes of risk management to include identification, assessment, analyses (qualitative), analyses (quantitative), allocation, monitoring and control of risks. Risk identification is the first step of the risk management process that involves identifying, categorizing and recording potential risks, together with information on their cause(s) and possible effect(s), which might affect the project [27]. The primary aim with the risk identification process is to generate a list of risks with both negative and positive consequences, which are called risk, register [23]. Risk identification and analysis may indicate the need for redesign, more detailed design, or different methods of construction in order to reduce risk [15] The purpose of risk analysis is to quantify the effects of the identified risks. The risk analysis techniques can be separated into three categories: qualitative, semi quantitative and quantitative methods [13]. Risk evaluation measures each step of the risk management model, and is an important indicator of an organisational effectiveness and efficiency in dealing with each of the steps in the process. Risk control involves taking measures to minimize the possibility of the risk occurring and/or to minimize the effects of the risk event in case such an event actually occurs [1].

[2] Suggested generally four response types to cope with risk. These are avoided, transfer, mitigate and accept. An effective risk management methodology can help to understand not the types of risks, but also how to manage these risks in different phases of a project. Managing risk in construction projects has been recognized as a very important management process in order to achieve the project objectives in terms of time, cost, quality, safety and 
environmental sustainability [30].

\section{Risk Factors Affecting Construction Projects}

Risk factors in construction project are enormous due to different activities involved, stakeholders, environment and the complex relationship among them.[15] attributed the causes of risks and uncertainties to performance of workers, material and quality, delays in supply of important materials to site, project budget and cost control, or the complexity of project procurement processes, which may threaten the project objectives.

[19] in a study of factors affecting construction costs in Mara large construction project identified 24 factors. [29] classified all construction risks into three levels, namely; country level risks which are external to the project and a function of the political and macroeconomic stability; market level risks which include availability of construction resources, complexity of regulatory processes and attitude of local and foreign governments towards the construction industry and project level risks which are specific to construction sites and include logistics constraints, improper design, site safety, proper quality control and environmental protection, etc.

[5] identified the risk factors affecting cost performance as tight project schedule, design variations, variations by the client, unsuitable construction programme planning, occurrence of dispute, price inflation of construction materials, excessive approval procedures in administrative government departments, incomplete approval and other documents, incomplete or inaccurate cost estimate and inadequate programme scheduling. [18] Conducted a research using exploratory survey method and broadly categorized risks in construction projects into internal and external sources. The internal risk sources, which fall under the control of clients, consultants and contractors, include those risk elements emanating from their acts or omissions in the project development process. While external risk sources, which are not within the control of clients and project team could be segregated into economic and globalisation, dynamics, unforeseen circumstances, force majeure, government, statutory, political controls, health and safety risk elements (which fall outside the control of the project team) and socio-cultural issues.

[8] Identified economic risk as the most significant in the Kuwaiti construction industry due to the boom in construction activities and inflationary trend of the market. Hence the study investigates the relationship between fluctuation cost and cost variation of building projects.

\section{Research Methodology}

The population of this study is made up of completed public building projects between 2015 and 2017 in the
South-South zone of Nigeria. Twenty of the projects were purposively sampled and adopted for the study. The data collected from the contractors` contract documents includes: project original contract sum, final contract sum and approved fluctuation. Linear regression was adopted to predict fluctuation cost based on cost variation of building projects. All the analyses were carried out at $5 \%$ level of significance and $95 \%$ level of confidence. The relationships among the variables are depicted below:

$$
\mathrm{VAC}=\mathrm{a}+\mathrm{bFLC}(\text { equation } 1)
$$

$$
\begin{aligned}
& \text { Where } \\
& \mathrm{y}=\text { VAC (cost variation) } \\
& \mathrm{a}=\text { Constant (co-efficient of intercept) } \\
& \mathrm{b}=\text { Regression Coefficient } \\
& \text { FLC = fluctuation cost }
\end{aligned}
$$

\section{Presentation and Analysis of Data}

This section presents data for the study and empirical analysis of the relationship between fluctuation cost and cost variation of building projects. The obtained data is from completed public building projects between the periods of 2015 to 2017. The secondary data was organized using spread sheets and analyzed using SPSS version 17.0 as presented in Table 1.

\section{Discussion of Results}

The study sought to establish a relationship between fluctuation and cost variation of building projects. The result of the analysis shows that the linear relationship between fluctuation cost and cost variation of building construction project in South-South zone of Nigeria is $\mathrm{VAC}=5.2950+1.3333 \mathrm{FLC}$ where VAC is the cost variation and FLC is fluctuation cost of building projects. The equation indicates that there is a direct relationship between cost variation of building projects and fluctuation in the prices of building materials and labour. The P-value of the slope of model 0.003 is less than $\alpha(0.05)$ therefore Ho is rejected and it is concluded that cost overrun of building project can be significantly explained by fluctuation in the prices of building materials and labour in the study area. The coefficient of determination or adjusted $\mathrm{R}^{2}(0.970)$ shows the extent to which changes in the cost variation of building projects varies with the independent variables - fluctuation cost. This indicates that the total changes in cost variation can be explained 97 percent by the changes in the fluctuation cost. The adjusted $\mathrm{R}^{2}$ value also indicates that the model $(0.97)$ is perfect.

\section{Conclusions and Recommendations}

The study revealed that a positive relationship exists between cost variation and fluctuation cost in the zone as a 
result of changes in the basic prices of materials and labour. Fluctuation which is occasioned principally by change in prices of materials and labour during the life of the construction period is a key determinant for effective project delivery. Its effect in most cases determines the success or failure of the project. The need to envisage with some reasonable degree of certainty, the likely changes in material and labour prices is very paramount in every construction project. This can be achieved with some degree of success by creating a material and labour price data base and using trend studies. Basic prices of construction materials and labour derived from archives of similar projects recently completed will help in assessing their impact with reasonable level of certainty. Finally, providing not only adequate but also reasonable contingency sum for construction projects will go a long way in absorbing cost sucks of cost variation resulting from fluctuation. It is recommended that there should be some levels of price forecast to enable tenderers absorb likely variation areas in the future before submitting final bid value. Project implementation should commence as soon as possible without delay by the stakeholders. Finance meant for the project must be made available before award of project.

Table 1. Final Cost (Account), Estimated Cost, Variation Cost and Fluctuation Cost

\begin{tabular}{|c|c|c|c|c|}
\hline Projects & Final Account Mil.(\#) & Estimated Cost Mil.(\$) & Variation cost Mil.( & Fluctuation Cost Mil.(\#) \\
\hline 1 & 733 & 568 & 165 & 112 \\
\hline 2 & 70 & 56 & 14 & 8.5 \\
\hline 3 & 226 & 185 & 41 & 20 \\
\hline 4 & 86 & 68 & 18 & 7 \\
\hline 5 & 50 & 40 & 10 & 7 \\
\hline 6 & 150 & 142 & 28 & 17 \\
\hline 7 & 155 & 130 & 25 & 20 \\
\hline 8 & 66 & 48 & 18 & 10 \\
\hline 9 & 40 & 35 & 5 & 5 \\
\hline 10 & 1500 & 1380 & 120 & 90 \\
\hline 11 & 28 & 22 & 6 & 4 \\
\hline 12 & 28 & 19 & 9 & 5 \\
\hline 13 & 145 & 100 & 45 & 40 \\
\hline 14 & 30 & 25 & 5 & 3.5 \\
\hline 15 & 18 & 12 & 6 & 3 \\
\hline 16 & 12 & 9 & 3 & 2 \\
\hline 17 & 3300 & 3060 & 240 & 180 \\
\hline 18 & 82.5 & 60 & 22.5 & 20 \\
\hline 19 & 165 & 142.5 & 22.5 & 10 \\
\hline 20 & 331.5 & 234 & 97.5 & 56 \\
\hline
\end{tabular}

Source: Surveyed data (2017)

\section{REFERENCES}

[1] Al-sobiei, O.S., Arditi, D. and Polat, G.(2005). Predicting the risk of contractor default in Saudi Arabia utilizing artificial neural network (ANN) and genetic algorithm (GA) techniques. Construction Management and Economics, 23, 423-430

[2] Artto, K., Kujala, J. and Martinsuo, M. (2005). Projektiliiketoiminta, Tuotantotalouden osasto, Teknillinen korkeakoulu, Espoo, 2005.

[3] Azhar, N., Farooqui, R.U. and Ahmed, S.M. (2008). Cost Overrun Factors in Construction Industry in Pakistan. Proceeding of First International Conference on Construction in Developing Countries (ICCIDE-1), Karachi, Pakistan, 4-5 August, pp: 499-508,

[4] Ballard, G. and Howell, G. (1998). "What kind of Production is Construction?” Proc. 6thAnnual Conf. Int'l. Group for Lean Construction, Sao Paulo Brazil, August
13-15.

[5] Cha, H. S. and Shin, K. Y. (2011). Predicting Project Cost Performance Level by Assessing Risk Factors of Building Construction in South Korea.

[6] Construction Clients' Forum (1994) http://www.constructin gexcellence.org.uk/sectorforums/constructionclientsgroup/h istory.jsp

[7] Elbing, C. and Alfen, H. W. (2005). Risk Management for Public Partners Private Partnership Projects and Project Portfolio from an Investor's Perspective, Proceedings of Queen Land University of Technology Research Week International Conference Held in Queen Land University of Technology, 4-8 July.

[8] El-Sayegh, S. M. (2008). Risk Assessment and Allocation in the UAE Construction Industry: International Journal of Project Management, volume 26, 431 - 438.

[9] Erkoyuncu, J. A., Roy, R., Shehab, E. and Wardle, P. (2009) Uncertainty challenges in service cost estimation for product- service systems in the aerospace and defence industries CIRP IPS2 Conference. Proceedings of the 1st 
CIRP Industrial Product-Service Systems (IPS2) Conference, Cranfield University, 1-2 April, pp.200.

[10] Flyvbjerg (2002). “Underestimating Costs in Public W orks Project: Error or Lie?” Journal of the American Planning Association, 68(3): 279-295.

[11] Greene, A. (2005). A Process Approach of Project Risk Management. Research student, Department of Civil and Building Engineering, Loughborough University

[12] Heizer, J. and Render, B (1996). Production and operations management strategic and tactical decisions, fourth ed. New Jersey, Prentice Hall international, 1996.

[13] ISO 31000:2009 (2009): Risk Management Principles and Guidelines. International Organization for Standardization, Geneva.

[14] Jaafari, A. (2001). Management of Risks, Uncertainties and Opportunities on Projects: Time for a Fundamental Shift. International Journal of Project Management, (19): 89-101.

[15] Khumpaisal, S. (2007). Risks in the Construction Project Procurement Process and the Mitigation Methods. Journal of Architectural/Planning Research and Studies; Facultyof Architecture and Planning, Thammasat University 5 (2): 133-146.

[16] Long, L.H., Young, D.L., \& Jun, Y.L..(2008). Delays and cost overrun in Vietnam large construction projects: A comparison with other selected countries. KSCE Journal of Civil Engineering, 12, 367-377.

[17] Mark, W., Cohen, P. E. and Glen, R. P. (2004) Project Risk Identification and Management. AACE International Transaction. INT.01.1-5.S (2004).

[18] Mbachu, J.I.C. and Vinasithamby, K. (2005). Sources of risks in construction project development: an exploratory study, proceedings of the Queensland University of Technology Research Week, Brisbane, Australia.

[19] Memon, A.H., Rahman, I.A., Abdullah, M.R. and Azis, A.A.A. (2010). Factors affecting construction cost in Mara large construction project: Perspective of project management consultant. International Journal of Sustainability in Construction Engineering Technology,
1(2).

[20] Odeyinka, H. A., Oladapo, A. A., \& Akindele, O. (2006). Assessing risk impacts on construction cost. Paper presented at the COBRA 2006-The construction and building research conference of the Royal Institution of Chartered Surveyors, University College London.

[21] Olsson, R. (2007). In search of opportunity management: Is the risk management process enough? International Journal of Project Management, 25, 745-752.

[22] PMBOK. (2004), A Guide to Project Management Body of Knowledge, 3rd Edition, Project Management Institute, USA.

[23] Project Management Institute. (2004). A Guide to the Project Management Body of Knowledge. Newtown Square, Pennsylvania: PMI.

[24] Patrick X.W., Guomin, Z, and Jiayuan, W. (2007) Understanding the key risks in construction projects in China. International Journal of Project Management, (25): 601-614

[25] Poon, J. (2003). Professional ethics for surveyors and construction project performance: what we need to know, in COBRA 2003: Proceedings of the RICS Foundation Construction and Building Research Conference, COBRA, Wolverhampton, England, pp. 232-242.

[26] Scott Cullen (2005.Risk Management. Journal of Arboriculture 31(3): May 2005.

[27] Shehu, Z. and Sommerville, J. (2006), Real Time Risk Management Approach to Construction Projects, Glasgow Calonian University, Glasgow, United Kingdom.

[28] Teneyuca, D. (2001). Organizational leader's use of risk management for information technology. Information Security Technical Report, 6(3): 54-59.

[29] Wang, J. Y. and Liu, C. L. (2004). Risk Management for Construction Projects, Beijing: China Water Publication.

[30] Zou, P.X.W., Zhange, G. and Wang, J.Y, (2007). Identifying key risks in construction projects: life cycle and stakeholders perspectives. In: Proceeding $12^{\text {th }}$ Pacific Rim Estate Society Conference, Aucland, New Zealand, pp 22-25. 